\begin{tabular}{|l|l|l||}
\hline \multicolumn{2}{|c|}{ PublisherInfo } \\
\hline \hline PublisherName & $:$ & BioMed Central \\
\hline \hline PublisherLocation & $:$ & London \\
\hline \hline PublisherImprintName & $:$ & BioMed Central \\
\hline \hline
\end{tabular}

\title{
Molecular mimicry and autoimmunity
}

\begin{tabular}{|l|l|l||}
\hline \multicolumn{2}{|c|}{ ArticleInfo } \\
\hline \hline ArticleID & $:$ & 232 \\
\hline \hline ArticleDOI & $:$ & $10.1186 /$ ar-1999-66743 \\
\hline \hline ArticleCitationID & $:$ & 66743 \\
\hline \hline ArticleSequenceNumber & $:$ & 189 \\
\hline \hline ArticleCategory & $:$ & Paper Report \\
\hline \hline ArticleFirstPage & $:$ & 1 \\
\hline \hline ArticleLastPage & $:$ & 3 \\
\hline \hline & & RegistrationDate : 1999-11-5 \\
\hline ArticleHistory & $:$ & OnlineDate \\
\hline \hline ArticleCopyright & $:$ & Current Science Ltd1999-11-5 \\
\hline \hline ArticleGrants & $:$ & \\
\hline \hline ArticleContext & $:$ & 130753311 \\
\hline \hline
\end{tabular}


Aff1 Institute Molecular Medicine, Oxford, UK

\title{
Keywords
}

\author{
Autoimmunity, molecular mimicry, peptide,TCR flexibility
}

\section{Context}

The interaction between the T cell receptor (TCR) and its major histocompatibility complex (MHC) peptide ligand has been shown to be more promiscuous than was originally supposed, with a given TCR often being able to recognise several different peptides presented by an MHC molecule. It is possible therefore, that $\mathrm{T}$ cells primed by a foreign antigen may be able to recognise a related, but not identical, peptide from a self-antigen. In such cases infection may trigger autoimmune disease. To examine molecular mimicry as a mechanism for $\mathrm{CD} 8^{+} \mathrm{T}$ cell mediated autoimmunity.

\section{Significant findings}

Sixteen peptides from rodent proteins, with homology to the gp 33 peptide, were identified and found to bind to H-2Db. Six of these peptides induced proliferation of naive T cells from the TCR Tg mice, and one peptide was capable of inducing cytolytic effector function in naive $\mathrm{T}$ cells from the $\mathrm{Tg}$ mice. Five peptides could be detected in cytotoxicity assays using activated T cells from the TCR Tg mice.

One of these peptides, $\mathrm{mDBM}$, a partial agonist/antagonist peptide from the enzyme dopamine ?mono-oxygenase was chosen for further study. The enzyme dopamine ?-mono-oxygenase is expressed by adrenergic neurons and by chromaffin cells in the adrenal medulla and is responsible for the conversion of dopamine to noradrenaline.

Control experiments showed that there was limited viral replication in the adrenals after high dose LCMV infection and that virus could not be detected in the adrenals after low dose infection or after infection with recombinant vaccinia virus vacc-Gp.

Infection of the TCR Tg mice with LCMV did, however, result in T cell infiltration of the adrenal medulla (specifically) and this correlated with an increase in levels of adrenal dopamine (consistent with a failure of the chromaffin cells to convert dopamine to noradrenaline). 
Infection of control C57BL/6 mice with LCMV resulted in low levels of virus in the adrenals with some $\mathrm{T}$ cell infiltrate. This, however, was not specific for the medulla and was not associated with a rise in adrenal dopamine.

\section{Comments}

\section{Methods}

A TCR transgenic (Tg) mouse was constructed, expressing a receptor (P14) specific for an epitope from the lymphocytic choriomeningitis virus(LCMV) glycoprotein (gp) 33, presented by the MHC class I molecule $\mathrm{H}-2 \mathrm{Db}$. The ability of related self-peptides to stimulate the $\mathrm{P} 14 \mathrm{Tg} \mathrm{T}$ cells from the mouse was examined in vitro and several such self-peptides were identified. The potential for LCMV to induce autoimmunity by stimulating Tg T cells to react with the self-peptides in vivowas examined.

\section{References}

1. Ohteki T, Hessel A, Bachmann MF, Zakarian A, Sebzda E, Tsao MS, McKall-Faienza K, Odermatt $\mathrm{B}$, Ohashi PS: Identification of a cross-reactive self ligand in virus-mediated autoimmunity. Eur J Immunol. 1999, 29: 2882-2896.

This PDF file was created after publication. 